\title{
CHRISTIAN HENGSTERMANN
}

University of Münster

\section{Robert Erlewine. Monotheism and Tolerance: Recovering a Religion of Reason. Indiana University Press, 2010.}

Erlewine's monograph Monotheism and Tolerance. Recovering a Religion of Reason offers a plea for the religious philosophies of three of the foremost representatives of what the author terms the 'Enlightenment religion of reason trajectory'. Two of them, Moses Mendelssohn and Hermann Cohen, are Jewish, one, Immanuel Kant, Christian. The three authors examined, the author holds, put forth an account of religion that may help to reconcile modern religious pluralism and the self-conception of monotheistic religion, including its belief in historical revelation and election, without the latter having to abandon its distinct identity.

In his introduction, Erlewine gives an in-depth analysis of the precarious connection between monotheistic faiths and violence, with which contemporary critics of religion, notably Jan Assmann, have charged the three Abrahamic religions. Following Assmann and others, Erlewine reveals the intolerance and proneness to violence inherent in monotheism to be rooted in its highly agonistic "dynamic between particularity and universality, wherein", the author proceeds to explain, "a particular community is imbued with universal significance, and as a result is brought into conflict with all other particular communities, which lack this universal significance" (p. 10). Thus, in monotheistic faith, a particular historical community, entrusted with divine revelation, is tasked by God with spreading a message of universal significance with the eschaton at the end of salvation history bringing about the hoped-for conversion of all mankind. Moreover, the message revealed bears upon the metaphysical telos of man's very nature so that the Other outside the divinely-privileged community is bound to fall short of human nature as such. Worse still, as well as missing the aim intrinsic to her nature, the religious Other comes to be seen as positively defying divine providence. However, while there is no denying its proneness to violence, the dialectic between particularity and universality is so essential to the discursive structure of scriptural universalism that modern theories of religious pluralism, which seek to remedy the evident potential of violence intrinsic 
to Abrahamic monotheism by rejecting the primacy of any one religion, fail to offer viable alternatives for the faithful. According to Erlewine, it is the chief merit of the three thinkers he sets out to discuss that they all espouse enlightened philosophies of religion while also - with varying degrees of success - preserving both the logic of elective monotheism and the concomitant intolerance of the religious Other. However, theirs is shown to be an intolerance that shuns violence both on the conceptual and physical level with the respect for the humanity in the person being the overriding aim of their Enlightenment religious philosophy.

Integrating the conflicting notions of the election of the Jews and cultural equality into a first draft of Enlightenment rational theology, Jewish philosopher Moses Mendelssohn, whose thought has been unduly neglected in the past, marks the beginning of the religion of reason trajectory. Contrary to those strands in modern Mendelssohn scholarship that pass over the election of the Jewish people as peripheral to his systematic philosophy, the author points out that the attempt to reconcile Jewish elective monotheism and universal rational religion is, in fact, at the fore of the philosopher's mature religious thought. In accordance with his perfection, Mendelssohn's God cannot but have created the best possible world, within which man, as a rational being, takes pride of place. The only being endowed with moral freedom and the ability to strive for individual perfection, man as such is of infinite worth. As a consequence, Mendelssohn is aghast at the notion of eternal damnation which he deems incompatible with a perfect God who, he avers, is unwilling ever to sacrifice the infinite value attaching to a rational being. It is for the sake of his infinite worth as well that man is entitled to believe in an afterlife in which he may continue his perpetual striving. Significantly, Mendelssohn is keenly aware of the blatant contradiction between his vision of rational universalism and his own inherited elective monotheism. Hence, he rules out revelation as the sole means to salvation, insisting that the eternal truths of rational religion, to which man is privy by his capacity of reason alone, is sufficient to achieve the telos of individual perfection. Nevertheless, Mendelssohn, despite his outspoken rational universalism, is unwilling to part with the pre-eminence of Jewish monotheism in favour of a position of religious pluralism and relativism akin to John Hick's. Instead, he seeks to preserve the dialectic of universality and particularity so crucial to elective monotheism by 
introducing into his account of rational religion the concept of idolatry. While lacking in systematic coherence, Mendelssohn's notion of idolatry serves as an umbrella term for all kinds of aberrations from rational religion both in philosophy and theology. Significantly, it is with regard to his day's Christianity, the prime example of irrational depravations in religion, that Mendelssohn elaborates his key concept. Christianity, for Mendelssohn, is a "living anachronism" (p. 54) evidencing the dangers resulting from scriptural universalism that, lacking rational correction, is at odds with the early modern ideal of tolerant egalitarianism. Positing belief in Christ as the sine qua non of salvation, Christianity misconstrues the arbitrary revelation of an unfathomable deity as the only means to attain salvation. Hence, the Christian God, conceived along the lines of scriptural voluntarism, emerges as a gruesome despot who, meting out grace according to his inscrutable counsels, denies man the due value which rational religion bestows upon him as a moral being: The dogma of original sin and the eternal damnation it entails robs the vast majority of mankind of any worth whatsoever. Conversely, Judaism is deemed the historical "emissary of reason" (p. 60). Pending the eschatological conversion of the whole of mankind to their original religion of reason, the Jews, entrusted with a special revelation, are called upon to witness to the religion of reason in a world that is still haunted by the spectre of idolatrous irrationalism. By practicing the rites prescribed by Halakha, Mendelssohn's chief example of Jewish revelation, Israel serves as a priestly nation reminding others of the frequently-forgotten religion of reason from which they have strayed. However, it is here that the gap between elective monotheism and rational theology becomes apparent, as Mendelssohn fails to provide any systematic whys and wherefores of Halakha serving a vital function within rational theology. In fact, both God's election of the Jews and his special revelation of Halakha stem from his inscrutable will, thus proving an unenlightened remnant of scriptural universalism that co-exists somewhat uneasily with Mendelssohn's rational theology and cultural egalitarianism. In the end, Mendelssohn, for all his outspoken religious rationalism, acquiesces in commending the fate of a largely idolatrous world to the incomprehensible counsels of the deity of Holy Writ, viewing Jewish election as only loosely, if at all, linked with the eventual triumph of Enlightenment religion. 
Famously, Kant's historic attempt at a Religion within the Limits of Reason Alone translates Christian religion and the teaching of Christ, the supreme moral philosopher, into rational ethics. With theoretical reason bereft of its access to God in principle, practical reason alone may lay legitimate claim to knowledge about the divine. Avoiding Mendelssohn's rather inconclusive co-existence of rational and scriptural universalism, Kant is unequivocal in his rejection of the unfathomable deity of the biblical tradition. Moreover, not only is scriptural universalism, which, in Kant's account, vainly purports to offer both theoretical insight into and extra-ethical ways to attain to the divine, stripped of its religious legitimacy, but also deemed an obstacle to the practical religion of pure reason. Indeed, in his scathing criticism, Kant charges traditional religion with being subject to radical evil, as it posits self-love and the striving for individual happiness rather than perfection and disinterested love for mankind as the supreme maxim of man's action. Thus, man, instead of undertaking the arduous task of moral self-reform, is tempted into preferring to seek happiness by pandering to the whims of a divine despot. Scriptural religions, moreover, can be seen to be driven by a misguided universalism, as they fulfil their allegedly divine duty to spread their message. Their attempt, however, is doomed from the beginning, as arbitrary revelation, upon which their claim to universality is based, can never hope to engender a universal consensus. In the end, as is shown by ample historical evidence, it is only by resorting to violent means that scriptural religions can hope to enforce their alleged truth. Thus, Kant, surprisingly, exposes the traditional monotheistic creeds as subverting their very raison dêtre, i.e. the unity of mankind in pursuing the one telos of the ethical commonwealth. At the heart of Kant's ethics of autonomy, as Erlewine shows, lies a social ideal that is conditional upon the perspective of moral universality replacing that of eudaimonistic particularity. In keeping with his rational theology, Kant's ethical commonwealth, recognizing man's finitude and utter ignorance of the divine, consists in man's common moral striving to overcome radical evil and unsocial sociability. This effort is necessarily a collective one, as man must positively engage with the Other in joint reflection and mutual critique in order to achieve the highest aim of practical reason: "Kant's new anthropocentric, anti-foundationalist conception of reason", concludes the author, "is public in nature, and rooted in discourse rather than the 
dogmatic algorithms of (non-critical) rationalist metaphysics" (p. 123). In so doing, it certainly overcomes the violent intolerance inherent to elective monotheism, while still retaining some of its key notions such as its missionary effort in salvation history and its eschatological fulfilment in the kingdom of God. Nevertheless, in the end, Kant's concept appears flawed on numerous grounds: For one thing, Kant vacillates about key notions of Christian faith which he sets out to translate into pure practical reason. Thus, while rejecting the idea of man's original sinfulness as a contradiction in terms, his notion of radical evil, which, by denying the moral law its due primacy, mars man's every maxim, comes so close to it as to be virtually indistinguishable from it. For another, Kant's ethico-theology, while seeking to end religious strife once and for all, also introduces a new antagonism, as the new Enlightenment religion must struggle to overcome the unenlightened religions of old. Above all, Kant's ethical kingdom of ends, which his rational universalism introduces as the rational substitute for the kingdom of God in the biblical vision of universality, emerges as a highly inconsistent "form of politics rooted in morality and not politics as such, a non-politics to counter worldly politics" (p. 115). Kant's explanation of how the ethical commonwealth is to be brought about in a joint effort of human morality and divine grace, thus, remains elusive at best.

Hermann Cohen, whose religious philosophy Erlewine regards as the most promising of the three Enlightenment approaches examined, chooses to retain the intolerance essential to elective monotheism, thus doing justice to the basic self-conception of monotheistic religion. However, Cohen's is a humane notion of intolerance that rests upon the foundation of a complex ethical hermeneutics of the Jewish holy writ. Seeking to bridge the fateful chasm between rational and scriptural universalism, he posits that, historically, the former originally inheres in and develops from the latter. His method is twofold: Firstly, he subscribes to Kant's notion of a regulative ideal that, while never actually attained in the endless process of rational inquiry, guides our every scientific and philosophical effort. Secondly, the method of "correlation", derived from and closely related to the regulative ideal of Kantian philosophy, fuses two concepts into a unity which affects the meaning of both and preserves their semantic distinctiveness at the same time. The idea of God, in Cohen's systematic thought, is truth. As such, it constitutes the 
core principle of reason that safeguards the dynamic correlation of the actual "is" and the possible "ought", i.e. the scientific and the ethical realms, which, in turn, serves as the indispensable rational foundation of all moral endeavour. Moreover, the very dynamic of the "ought" in the process of realization translates into the concept of human nature which is pivotal to Cohen's Enlightenment construal of rational religion. The regulative ideal for which both morality and religion strive is the totality of humankind conceived of in contradistinction from the egocentricities of particularity and the vested interests of plurality. It is here that religion and the philosopher's own Jewish creed play a major role, as the religious rationality of Judaism in particular impresses upon formal rational ethics the crucial correlation between God and man, and that between human beings, as well as the dimension of the interpersonal and human suffering. Like Kant's rational religion, Cohen's, thus, is chiefly practical. However, whereas Kant, for all his praise of Christianity, is wary of attributing to it a special historical role, Cohen, besides the correlations between God and man and that between human beings, holds to the correlation of God and his chosen people as well, thus preserving a key idea of elective monotheism. In the course of history, he posits, this latter correlation, which bears on the Jewish people's historical ministry in spreading the monotheistic creed, decisively shapes the first and the second: Though tracing the history of a particular people, the Hebrew Bible is instrumental in bringing about the moral ideal of universality, as the Jewish revelation, whose multiple historical phases amount to a gradual rationalization of ethical monotheism, leads mankind as a whole towards rational universalism. Rather than being the incomprehensible divine being of scriptural universalism, the unique God of Israel's historical monotheism, in his correlation with his chosen people, is conceived of as the highest ideal of practical reason, the unity of mankind. In that, the relation between God and humanity is, in fact, so close as to verge on identity, as dictated by Cohen's logic of correlation: The God whom Israel worships in its biblical history is the foundation of man's transcending his mere "is" towards a holy "ought". In turn, the universality of mankind, for whose sake the Jewish people bears witness, is the only means whereby God becomes apparent in the world.

It is to the credit of Erlewine's fine analysis that he rediscovers the systematic significance of Enlightenment philosophy of religion in 
general and a frequently-neglected author of the much-maligned NeoKantian school of thought in particular. Among the numerous merits of Cohen's religious philosophy, the author shows, is the relative paucity of its metaphysical commitments, which sets it apart both from Moses Mendelssohn's whole-scale Leibnizean rationalism and Immanuel Kant's equally complex practical metaphysics. All in all, Erlewine's searching analysis of key thinkers of the ongoing project of enlightenment is a fine example of the systematic significance that may accrue to careful studies of hitherto underappreciated representatives of Enlightenment thought. Hence, while eventually revealing both Mendelssohn and Kant's approaches to be inconsistent or flawed, their analyses of the inherent problem of elective monotheism are shown to be highly apposite and paving the way for Cohen's systematically valid philosophy of moral monotheism. 